\title{
PSYCHOLOGY
}

\section{ФІЗКУЛЬТУРНО-СПОРТИВНА ДІЯЛЬНІСТЬ ЯК ФАКТОР ЛЕГІТИМІЗАЦІї АГРЕСИВНОСТІ У ПЕРІОД ЮНОСТІ}

\author{
Koval Hanna, \\ Associate Professor, Odessa I.I. Mechnikov National University, \\ Department of Social and Applied Psychology, Faculty of Psychology and Social Work; \\ Rosenberg Irina, \\ Senior Lecturer, Odessa National Maritime University, Department of Physical Education and Sports, \\ Master of Sports in Table Tennis \\ Braslavsky Igor, \\ Senior Lecturer, Odessa National Maritime University, Department of Physical Education and Sports, \\ international master of sports in athletics
}

DOI: https://doi.org/10.31435/rsglobal_ws/30042020/7037

\section{ARTICLE INFO}

Received: 16 February 2020

Accepted: 12 April 2020

Published: 30 April 2020

\section{KEYWORDS}

aggression,

physical education,

legitimization,

students,

individual psychological features,

prevention,

heavy law enforcement.

\begin{abstract}
According to the General Prosecutor's Office, in 2019-2020 in Ukraine, the total number of crimes decreased, but at the same time the number of some grave and especially grave ones increased, for which prison terms are provided up to life imprisonment. Law enforcers also note an increase in juvenile delinquency with a tendency to particular cruelty. Obviously, the types of these serious crimes are associated with the level of the general index of aggression of offenders. Considering, also, the high rate of relapse of crimes related to aggressive behavior, we should talk about the special relevance and acuteness of this socio-psychological problem. In the article, the authors cite research data on the legalization of aggressiveness, taking into account the individual psychological characteristics of the individual and mesofactors: joint physical culture and sports activities at the level of a close social environment. An analysis of the results of the study indicates that the main group of students engaged in physical education and sports sections during 4 years of study at a university demonstrates significantly lower indicators of psychological and psychological characteristics indicating potential aggressiveness than the control group of students who did not engage in physical education / sports during the specified period.
\end{abstract}

Citation: Koval Hanna, Rosenberg Irina, Braslavsky Igor. (2020) Fizkulturno-Sportyvna Diialnist yak Faktor Lehitymizatsii Ahresyvnosti u Period Yunosti. World Science. 4(56), Vol.3. doi: 10.31435/rsglobal_ws/30042020/7037

Copyright: (C) 2020 Koval Hanna, Rosenberg Irina, Braslavsky Igor. This is an open-access article distributed under the terms of the Creative Commons Attribution License (CC BY). The use, distribution or reproduction in other forums is permitted, provided the original author(s) or licensor are credited and that the original publication in this journal is cited, in accordance with accepted academic practice. No use, distribution or reproduction is permitted which does not comply with these terms.

Вступ. Соціально-економічні перетворення в Україні породили ряд негативних громадських трансформацій, що актуалізують деструктивні тенденції серед населення. За даними Генеральної прокуратури, у 2019 році в Україні істотно знизилася загальна кількість злочинів, але при цьому збільшилася кількість тяжких та особливо тяжких, за які передбачені тюремні терміни аж до довічного. Відповідно до Кримінального Кодексу України, до них відносяться: вбивства, згвалтування, пограбування, розбій, тяжкі тілесні ушкодження. Правоохоронці констатують, також, зростанні юнацької злочинності з тенденцією до особливої жорстокості. 
Очевидно, що види цих тяжких злочинів пов'язані з високим рівнем загального індексу агресивності правопорушників. Враховуючи, також, високий рівень рецидиву злочинів, пов'язаних 3 агресивною поведінкою, слід говорити про особливу актуальність і гостроту цієї соціально-психологічної проблеми.

Тяжкі правопорушення, які зазвичай пов'язують з поняттями «агресія» і «агресивність», вже давно стали предметом суперечок серед тих, хто займається вивченням цього феномена, а їх профілактика та корекція досі є однією з серйозних і складно розв'язуваних проблем.

Аналіз спадкових та біологічних детермінант агресії представлено в роботах Л.М. Балабанової, І.О. Віденєєва, А.Ш. Коваль, М.А. Кузнецова, К. Лоренца, Д. Зільмана та ін.; психологічних детермінант - Л. Берковіц, Д. Долларда, Н. Міллера та ін. Вплив хімічних речовин на появу агресії досліджували Т. Румянцева, С. Тейлор, К. Леонард, Р. Шунтіх та ін. Взаємозалежність агресії та статі проаналізовано в працях таких вчених, як: Е. Бімен, Г. Берд, Г. Кларк, К. Мойер та ін.

Агресію як соціальний феномен і як специфічну поведінку досліджували як психологи, так і інші вітчизняні та зарубіжні фахівці - юристи, політологи, філософи, соціологи: О.М. Бандурка, Р. Берон, Є.В. Землянська, Є. Ільїн, А. Налгаджян, Д. Ольшанський, А. Реан, Д. Річардсон, Е. Фромм, С.І. Яковенко та ін. Аналіз наукових досліджень з проблеми дозволив зробити висновки про те, що термін «агресія» $€$ досить загальним і позначає дію або намір, що має за мету нанесення шкоди іншій людині.

Термін «агресивність» $є$ більш «вузьким». Велика психологічна енциклопедія трактує агресивність як стійку рису особистості; готовність до агресивної поведінки. Агресивність відноситься до групи біологічних факторів, що впливають на появу агресивності. Це спадковохарактерологічні, резідуально-органічні фактори та індивідуальні особливості людини.

Спадково-характерологічні фактори $є$ вродженими. До них належать вроджені інстинкти (наприклад, «потяг до смерті», 3. Фрейд; інстинкт самозбереження, К Лоренц) та генетична пам'ять. К. Юнг стверджував, що архетипи передаються з покоління в покоління не за рахунок культури, а за рахунок генетики, тобто накопичений досвід предків в боротьбі за виживання, мисливства, полювання та ін. передається сьогоднішньому поколінню на рівні генів і проявляється в формі захисної агресії. Сюди ж відносять особливості ЦНС, які закладені в людини генетично (прикладом може виступати тип ВНД: так, відомо, що сильний неврівноважений тип більш схильний до агресивної поведінки) [5].

Рівні агресивності визначаються як навчанням в процесі соціалізації, так і орієнтацією на культурно-соціальні норми, найважливіші з яких - норми соціальної відповідальності і норми відплати за акти агресії.

С.В. Березка соціальні фактори, які мають вплив на формування агресивності, підрозділяє на мікрофактори, мезофактори та макрофактори.

До групи «мікрофактори» належить вплив найближчого значимого оточення (референтної групи) - сім’ї, друзів; саме в найближчому оточенні людина переймає патерни поведінки, засвоює правила та норми, способи реагування та реакції на ті чи інші ситуації, i втому числі агресивні дії та вчинки.

До групи «мезофактори» вчений відносить вплив неблизького оточення (колективи в садках, школах, товариші), а також комп'ютерних ігор, засобів масової інформації та молодіжних течій в соціальних мережах.

Макрофактори передбачають вплив глобальних факторів на появу агресивної поведінки: соціально-політичні, економічні кризи в світі, війни, розвиток тероризму; ставлення суспільства до проявів агресії.

В окрему групу виділено «особистісний фактор» до якого відносяться індивідуальні психологічні особливості особистості. Наприклад: рівень сформованості самоконтролю (вміння контролювати власні емоції та дії, локус контрою); наявність вольових якостей (які забезпечують можливість прийняти рішення агресивної дії чи «не дії»), деяких особистісних рис (негативізм, злобність, впертість, ворожість, роздратованість, емоційна чуттєвість), особливості пережитого досвіду (наявність шаблонів реагування на події; пережите насилля; сформованості моральних поглядів та життєвих цінностей і т. д.), гендер (стать) [4].

Теоретичний аналіз стану проблеми агресивності демонструє наявність принципово різних підходів до розуміння сутності і природи агресії, що свідчить про багатоаспектність, 
багатоплановість досліджуваного явища; про багатофакторну обумовленість агресії як поведінкового акту і агресивності як властивості особистості.

Найбільш продуктивним, на наш погляд, представляється підхід, що виходить із обумовленості агресивних проявів в особистісних характеристиках і поведінці соціальнопсихологічними причинами.

Існує велика кількість засобів що до профілактики та корекції агресивності.

У роботі «Агресія. Так зване зло», яка вже стала класичною, К. Лоренц стверджує, що агресивність була обумовлена процесом внутрішньовидового відбору, який тривав багато тисячоліть і надав серйозний вплив на наших предків. Вчений, також, розуміє агресію скоріше енергетично, як те, що накопичується і вимагає розрядки [9].

А. Гуттман стверджує, що вихід агресії в спорті сприяє зниженню агресивності і в інших сферах суспільного життя. Вчений констатує, що це не стосується уболівальників, які випускають свій гнів під час футбольних сутичок. Тобто катарсис від перегляду змагань не призводить до соціально прийнятних способів вираження деструктивних емоцій, які могли б в іншій ситуації довести до скоєння вбивства або згвалтування. Відносно ж самих спортсменів, автор підкреслює, що агресивність їх знижується, але це пояснює цей факт тим, що під час занять вони витрачають велику кількість. Проте, агресія знижується [6].

Дослідження спортивних психологів А.С. Ашкеназі та В.Л. Маріщука свідчить, що заняття спортом сприяє «переключення» негативної побутової агресивності в здорову «спортивну злість», причому займаються єдиноборствами менш агресивні, ніж футболісти i важкоатлети [2].

Ю.А. Антонян констатує, що всім відомі численні скандали з титулованими боксерами і футболістами, які «раптом» виявлялися у в'язниці за згвалтування, п'яні бійки, хуліганство i членоушкодження [1]. Але ці дані, як стверджує Д.С. Шагако, $є$ виключенням 3 правил: результати обстеження спортсменів різних видів спорту, рівня кваліфікації та молоді, що не займається спортом, не дають підстав говорити про більшу агресивність спортсменів. Більш того, відмінності по ряду показників агресивності свідчать про більш виражені прояви конкретних форм агресії у не спортсменів [1].

Однак дослідження соціальної легалізації агресивності, як властивості особистості, за допомогою фізкультурно-спортивної діяльності вкрай розрізнені та дискусійні. 3 нашої точки зору, легалізація агресивності - це визнання факту наявності агресивності суб'єкта і можливість його прояву в соціально-прийнятої формі. Виходячи з думки, що високий рівень агресивності у структурі особистості є одним 3 факторів ризику розвитку противоправної поведінки, актуальність роботи обумовлена необхідністю ранньої превенції та легалізації агресивності у осіб юнацького віку.

Результати дослідження. В дослідженні прийняли участь 64 студенти 4 курсів різних факультетів та інститутів Одеського Національного Морського університету. Основна вибірка складалася із 32 осіб юнацького віку, які на протязі майже 4 років регулярно відвідували спортивні секції настільного тенісу і легкої атлетики та 32 осіб юнацького віку, які ніколи не займалися спортом або фізкультурою. При формуванні вибірки використано:

- Вікова періодизація Д. Бромлея (Bromley, 1966). Науковець поділяє цикл «юність» на 2 стадії: старше шкільне дитинство (11-15 років) та пізня юність (15-21 рік).

- Вікова періодизація у рамках біологічного підходу. По даним Малої медичної енциклопедії до юнацького відноситься період з 16 до 20 років.

- Кримінальний кодекс України. У частині 1 ст. 22 ККУ прямо зазначено, що «кримінальній відповідальності підлягають особи, яким на момент вчинення злочину виповнилося шістнадцять років». Цей вік називають загальним віком кримінальної відповідальності.

\section{Методи дослідження:}

- Теоретичні: синтез та аналіз джерел з психологічної літератури.

- Психодіагностичні: методика багатофакторного дослідження особистості

Р.Б. Кеттелла; багаторівневий особистісний опитувальник «Адаптивність» О.М. Маклакова і С.В. Черм'яніна; методика діагностики міжособистісних відносин Лірі; методика «Агресивна поведінка» (С.П. Ільїн , П.О. Ковальов); Тест - опитувальник К. Томаса на поведінку в конфліктній ситуації. 
- Методи описової математичної статистики та порівняльний аналіз.

Вибір психодіагностичних методик обумовлено соціально-психологічними якостями особистості, які діагностують ці методики, і які у сукупності можуть інтегрувати агресивність. При наявності такого фактора, як соціальна ситуація, сукупність цих якостей може стати тригером противоправної поведінки, що призводить до скоєння злочинів високого ступеня тяжкості і як моральним, так і прямим фізичним збитком для людині аж до летального результату.

Методика багатофакторного дослідження особистості Р.Б. Кеттелла використана для діагностики особистісних особливостей студентів за шкалами, які, на нашу думку, впливають на формування агресивності особистості [7].

Завдяки методиці "Адаптивність" О.М. Маклакова і С.В. Черм'яніна, оцінювались адаптаційні можливості особистості 3 урахуванням соціально-психологічних та деяких психофізіологічних характеристик, що відображають узагальнені особливості нервовопсихічного та соціального розвитку: нервово-психічну стійкість, комунікативні здібності, моральну нормативність, особистісний адаптаційний потенціал [11].

За допомогою методики діагностики міжособистісних відносин Т. Лірі досліджувалось уявлення суб'єкта про себе і ідеальне «Я» та особливості особистісних відносин по два чинникам домінування - підпорядкування і дружелюбність - агресивність [12].

За допомогою методики «Агресивна поведінка» Є. Ільїна, П.О. Ковальова оцінювалось стриманість - нестриманість досліджуваних та тип агресивної поведінки по наступним характеристикам: пряма вербальна агресія, непряма вербальна агресія, пряма фізична агресія, непряма фізична агресія [10].

За допомогою Тест - опитувальника К. Томаса оцінювались наступні стратегії поведінки у конфліктній ситуації: конкуренція (змагання), пристосування, компроміс, ухилення,співробітництво [13].

Аналіз вибірки студентів основної групи за методикою Р.Б. Кеттела, демонструє наступний розподіл типів темпераменту досліджуваних: $17 \%$ представників холероїдної групи, $32 \%$ - сангвіноїдної групи, 39\% - меланхолоїдної групи та $24 \%$ представників флегматоїдної групи. 3 урахуванням досліджень С.В. Агаркова та ін., можна констатувати наступне: найбільш високі показники ворожості, як одного з чинників агресивності природно мають меланхоліки та холерики; найбільші показники безпосередньо агресивності мають, також, холерики та трохи менш - меланхоліки. Якості нервової системи обумовлюють показники негативізму, дратівливості, вербальної, фізичної і непрямої агресії у представників холероїдної групи, а підозрілість і образливість, дратівливість і почуття провини $є$ якостями, які притаманні представникам меланхолоїдної групи. Розподіл типів темпераменту в основної виборці демонструє наявність $12 \%$ представників холероїдної групи, $36 \%$ - сангвіноїдної групи, $44 \%$ меланхолоїдної групи та $8 \%$ представників флегматоїдної групи. Таким чином, до ворожих та маючих агресивність типів в основної виборці відносяться 56\% студентів, до потенційно неагресивних - 54\% студентів.

Розподіл типів темпераменту у контрольної вибірці демонструє $10 \%$ представників холероїдної групи, $35 \%$ - сангвіноїдної групи, 44\% - меланхолоїдної групи та $11 \%$ представників флегматоїдної групи. Таким чином, до ворожих та маючих агресивність типів в контрольної виборці відносяться 54\% студентів, до потенційно неагресивних - 56\% студентів.

Зниження індексу агресивності спостерігається в ряду: холерікі $\rightarrow$ меланхоліки $\rightarrow$ сангвініки $\rightarrow$ флегматики.

Товариськість - це міжособистісні стосунки, які базуються на єдності інтересів у спільній діяльності і передбачають духовну (ідейну) єдність та відповідний ступінь рівності. По Шкала «товариськості - замкненості» 59,9\% студентів основної групи являються товариськими, охоче ідуть на контакт, легко встановлюють гарні відносини. У контрольної групі цей показник складає 39,7 \% студентів.

Емоційна стабільність - це здатність людини до збереження стійкості психічних i психомоторних процесів, до підтримки професійної ефективності в умовах впливу емоціогенних факторів; здатність стримувати, не проявляти емоції, зберігати спокій і спокійно реагувати на несприятливі обставини. Результати за шкалами - «емоційна стабільність емоційна не стабільність» демонструють досить високі показники емоційної стабільності, а саме 64,3\% (31,3\% - високий рівень та $33 \%$ середній рівень), що свідчить про урівноваженість 
студентів. У контрольній вибірці емоційно стабільних студентів 49,1\% (19\% - високий рівень, $30,1 \%$ - середній рівень).

Стриманість або утримання - моральна якість, яка вважається невідступним та свідомим пануванням розуму над пристрастями й іншими недобрими поривами. Шкала «стриманість експресивність», показує, що в основної групі 67,6\% студентів набрали високий результат по стриманості $(37,1 \%$ - високий рівень, 30,5\% - середній рівень). У контрольній групі стриманість притаманна 44\% досліджуваних (19\% - високий рівень, $25 \%$ - середній).

Нормативна поведінка - вид поведінки, що відповідає соціальним нормам. Аналіз результатів по Шкалі «нормативність» демонструє, що $72 \%$ опитаних 3 основної групи отримали високий результат ( $23 \%$ - високий рівень та $51 \%$ - середній рівень), що свідчить про їх вихованість та уміння відповідати соціальним стандартам. У контрольній групі показник нормативності - 49\% (9\% - високий рівень, 40\% - середній рівень).

Прямолінійність характеризується у бажанні людини висловлювати усі свою думки у чесній формі. Ця риса не є негативною, якщо людина прямолінійна в міру, якщо вона каже речі, які не зачіпають почуття інших людей. Але надмірна прямолінійність може бути ознакою вербальної агресивності. В основної групі по шкалі «прямолінійність - дипломатичність» ми спостерігаємо наступні дані: 59\% опитуваних мають високий рівень дипломатичності $(12 \%$ високий рівень, 47\% - середній рівень). У контрольній групі рівень прямолінійності перевищує рівень дипломатичності - відповідно, рівень дипломатичності складає $35,5 \%$ (8\% - середній рівень, 27,5\% - низький рівень).

Самоконтроль - це сукупність властивостей саморегуляції, пов'язана з усвідомленням особистістю самої себе. Даний блок надбудовується над усіма іншими блоками і здійснює над ними контроль: посилення або послаблення діяльності, корекцію дій і вчинків, передбачення i планування діяльності і т. д. Дані по шкалі «самоконтроль» показали, що 74,8\% студентів основної групи мають достатньо високі показники (52\% - високий рівень, $22,8 \%$ - середній рівень). У контрольній групі студентів показники самоконтролю знаходяться на середньому рівні - 49,1\% ( $3 \%$ - високий рівень, 46,1\% - середній рівень)

Психічна напруженість являє собою одну з форм цілісної психологічної реакції людини в екстремальних ситуаціях. Як і всякий стан, психічна напруженість є динамічним проявом всієї психології особистості в даний час або за певний часовий відрізок, особистісний динамічний феномен. Психічна напруженість за своїми основними психологічними ознаками цілісна, як цілісна психологія самої особистості. Вона структурна і многокомпонентна, як і психологія особистості, і не може бути окремим процесом або деякою сумою елементів психіки. Вона включає в єдності і взаємозв'язках мотиваційні, пізнавальні, емоційні, вольові та психомоторні прояви. Характеристики психічної напруженості в різних ситуаціях несуть на собі відбиток об'єктивної специфічності цих ситуацій і індивідуалізованої специфічності реакції особистості на них. У внутрішніх характеристиках психічної напруженості багато більше специфічноособистісного і специфічно-ситуативного ніж стандартного, енергетичного, що характерно для психологічного стресу. Результаті по шаклі «розслабленість - напруженість» - демонструють, що $67 \%$ відсоток досліджуваних основної групи мають високий ступень розслабленості $(18,9 \%$ високий рівень, $48,1 \%$ - середній рівень). У контрольній групі $43 \%$ студенти мають середній рівень розслабленості ( $2 \%$ - високий рівень, $41 \%$ - середній рівень).

По шкалам «інтелект», «підпорядкованість - самоствердження», «сміливість боязкість», «довірливість-підозрілість», «спокійність - тривожність», «практицизм чуттєвість», «екстраверсія - інтроверсія, «консерватизм - радикалізм» в основної та контрольної групах достовірних відмінностей не виявлено.

Діагностику адаптаційних здібностей проведено за допомогою методики О.М. Маклакова і С.В. Черм'яніна. Адаптивність - це здатність системи пристосовуватися до різних умов навколишнього середовища. Багато авторів пов'язують це поняття 3 такими економічними ознаками, як гнучкість, ефективність, конкуренція, стійкість. Біли отримані наступні результати. В основної вибірці переважна кількість опитаних має високий та достатній рівень адаптивності - 31,3\% та 55,6\% (86,99\%). Це свідчить, що ці студенти швидко адаптуються до незнайомих та стресових ситуацій, мають нервово-психічну стійкість на достатньому рівні та високу моральну нормативність. У контрольної групі студентів високий рівень мають 12,2\% опитуваних, середній - 46,3\% (58,5\%). Можна припустити, що 41,5\% 
студентів контрольної групи важко адаптуються до нових умов, схильні до конфліктів та асоціальних вчинків. 3 урахуванням сучасних наукових даних о позитивної кореляції ступеню дезадаптації з рівнем особистісної агресивності, можна припустити можливість негативного життєвого сценарію з тенденцією к правопорушенням [8].

Діагностику міжособистісних відносин у студентів юнацького віку було проведено за допомогою методики Т. Лірі. В цілому діагностика дозволила охарактеризувати більшу частину вибірки студентів, як тих, що з готовністю ідуть на контакт, підтримання гарних взаємовідносин та позитивної атмосфери, являються товариськими 3 оточуючими. В основної групі по шкалі «Домінування» 88,2\% мають помірний та високий рівень домінування (46\% - помірний, 42,2\% високий). У контрольній групі, відповідно, 72\% (41\% - помірний, 31 - високий). Але екстремально високий рівень домінування у студентів основної групи має $3 \%$ студентів, а у контрольній - $9 \%$. Така риса, як домінування, не є негативною сама по собі. Але за певних обставин призводить до проявів агресивності різного ступеню тяжкості у відношенні другої людини.

По шкалі «Дружелюбність» і основна, і контрольна вибірка студентів мають результати практично на одному рівні. В основній групі ці показники складають $69 \%$ (помірний рівень $44,7 \%$, високий рівень - 24,3\%). У контрольні групі це показник склав 70\% (помірний рівень $43 \%$, високий рівень - 27\%). Це свідчить, що більшість респондентів с готовністю ідуть на контакт, підтримують гарні взаємовідносини та позитивну атмосферу, являються товариськими 3 оточуючими. Але у контрольній групі низький показник складає $21 \%$ досліджуваних проти $9 \%$ в основної групі.

Діагностику рівня стриманості у конфліктних ситуаціях було проведено за методикою Ільїна Є.П. та Ковальова П.А. «Агресивна поведінка». Студентам основної вибірки притаманний високий - $18 \%$ та помірний - 55,4\% рівень стриманості у конфліктних ситуаціях $(73,4 \%)$. Студентам контрольної вибірки притаманний високий $-7 \%$ та середній $-51 \%$ стриманості (58\%). Проте у контрольній групі показники низького рівня значно вищі, ніж у контрольної, відповідно, $42 \%$ проти 27,4\%. Звісно, низька стриманість у конфліктних ситуаціях може стати тригером агресивної та, можливо, протиправної поведінки.

Різниця між групами спостерігається, також, по показникам фізичної та вербальної агресії. По першому показнику у основної групі високий рівень схильності до фізичної агресії мають $18 \%$ студентів, у контрольній - 31\%. До вербальної агресії схильні $21,4 \%$ досліджуваних основної групи та $43 \%$ студентів контрольної групи.

За методикою К. Томаса було виявлена різниця типів поведінки в конфліктних ситуаціях між досліджуваними представниками в обох групах. Отримані результати свідчать, що тип поведінки «співробітництво» мають $27 \%$ опитуваних основної групи та 15 контрольної. Ці студенти прагнуть долати труднощі через взаємодію з іншими, вони мають високий рівень дружелюбності. Слідуючи такому стилю, людина бере активну участь у вирішенні конфлікту, але при цьому намагається саме співробітничати з іншою людиною. Цей стиль вимагає складної та тривалої роботи, оскільки спочатку відкриваються потреби, інтереси всіх сторін конфлікту, а потім проходить активне їх обговорення. Для успішного використання стилю співробітництво необхідно витратити певний час на пошук прихованих інтересів іншої сторони.

Тип поведінки «компроміс» мають 22,4\% опитуваних основної групи та $21 \%$ контрольної. Ці студенти адекватно реагують на конфліктні ситуації, стараються знайти загальне рішення, яке б задовольнило обидві сторони конфлікту. Використовуючи стиль компромісу, людина трохи поступається власними інтересами, щоб задовольнити їх в іншому. Інша сторона робить те саме. Такі дії можуть певною мірою нагадувати співробітництво. Однак компроміс досягається на більш поверхневому рівні порівняно зі співробітництвом. Компроміс часто $€$ вдалим відступом чи навіть останньою можливістю прийти до певного рішення.

Тип поведінки «уникнення» мають $18 \%$ опитуваних основної групи та $22 \%$ контрольної. Для цього типу характерна як відсутність прагнення до кооперації, так i відсутність тенденції до досягнення власних цілей. Цей підхід реалізується тоді, коли людина не відстоює свої права, не співробітничає ні з ким для вирішення проблеми або просто ухиляється від конфлікту. Цей стиль можна використовувати цю тактику, коли вирішується не надто важливе питання або коли становище безвихідне. Не дивлячись на те, що багато хто вважає ухилення слабкістю, часто така «відстрочка» може стати шансом залагодити ситуацію. 
Тип поведінки «конкуренція» мають 15,6\% опитуваних основної групи та 26\% контрольної. Ці студенти прагнуть добитися свого, інколи шкодячи іншим, думаючи тільки за своє «я». Людина, що використовує стиль конкуренції, дуже активна і намагається йти до вирішення конфлікту власним шляхом. Вона не надто зацікавлена у співробітництві з іншими людьми, натомість $\epsilon$ здатною на вольові рішення. Згідно опису К. Томаса, вона намагається в першу чергу задовольнити власні інтереси за рахунок чужих, примушуючи інших людей приймати ваше вирішення проблеми. Задля досягнення мети вона використовує свої вольові якості.

Це може бути ефективним стилем в тому випадку, коли людина тримає в руках певну владу. Однак це не той стиль, який ефективно можна використовувати в спілкуванні між людьми.

Наведемо кілька прикладів випадків, коли можна використовувати стиль суперництва:

- підсумок є дуже важливим для людини;

- людина має певний авторитет для прийняття рішення і $є$ очевидним, що це рішення $\epsilon$ найкращим;

- коли немає іншого виходу;

- людина не може показати, що вона розгубилася.

Тип поведінки «пристосування» мають $17 \%$ опитуваних основної групи та $16 \%$ контрольної. Цей стиль означає те, що людина діє спільно з іншою людиною, не намагаючись відстоювати власні інтереси. Цей підхід можна використовувати, коли результат важливий для партнера та не дуже важливий для певної людини. Також стиль $є$ корисним в тих ситуаціях, коли партнер має більшу владу. Поступаючись, погоджуючись або жертвуючи власними інтересами, людина може пом'якшити ситуацію.

Жоден стиль поведінки в конфліктних ситуаціях не добрий і не поганий поза контекстом соціальної ситуації. Ми можемо говорити тільки про його продуктивність/непродуктивність в поведінкових стратегіях особистості. Проте, такий стиль поведінки в конфлікті, як конкуренція (суперництво) в певних обставинах, безумовно може призвести до негативних наслідків: сварок, скандалів бійок і вбивств.

Висновки. 1. Проведений загальнотеоретичний аналіз поняття «агресія» дозволив встановити, що це системна поліфункціональна властивість, яка формується в процесі соціалізації людини і залежить від комплексної взаємодії різних відділів нервової системи, механізмів гормонального регулювання, зовнішніх подразників і засвоєних реакцій. Термін «агресія» $€$ досить загальним і позначає дію або намір, що має за мету нанесення шкоди іншій людині. Агресивність трактується як стійка риса особистості; готовність до агресивної поведінки та відноситься до групи біологічних факторів, що впливають на іiі появу. Це спадковохарактерологічні, резідуально-органічні фактори та індивідуальні особливості людини. Базовою підставою агресивності є біохімічні та нейрофізіологічні особливості функціонування організму. Вчені підкреслюють, що агресивність пов'язана в першу чергу з маскуліністю, яка в свою чергу, пов'язана з фізичним розвитком і тестостероном. Це так званий психогенний базис агресивності. У процесі соціалізації формується соціогений базис, який може сприяти формуванню та реалізації агресивної поведінки. Все разом це створює «потенціал» агресивності.

Фізкультура і спорт, якщо розглядати їх як культурну практику, відображають загальну тенденцію сучасної культури (принаймні, тієї ії частини, яку можна назвати європейською) на локалізацію та усунення насильства та проявів агресивності в середині спільноти. У вищій школі фізична культура $є$ базовою галуззю освіти. Вона закладає основи фізичного і духовного здоров'я, на базі якого можливо різнобічний розвиток особистості, а також, може бути вирішальним фактором попередження і подолання агресивності та, як слідство, противоправної поведінки студентів юнацького віку.

2. Як демонструє аналіз результати дослідження, основна група студентів, які займалися у спортивних секціях на протязі 4 років, має суттєво нижчі показники особистісних якостей, які свідчать об агресивності та можуть стати тригером скоєння особливо тяжких злочинів, ніж контрольна група студентів, які не займалися фізкультурою/спортом на протязі навчання у ВН3. У основної та контрольної групах студентів кількість потенційно агресивних представників холероїдного та меланхолоїдного типу темпераменту практично однакові, що свідчить про однакову біологічну базу.

Представниці основної групи порівняно з представниками контрольної групи мають високі показники по наступним особистісним особливостям: товариськість, емоційна 
стабільність, стриманість, нормативність, самоконтроль. Значно нижчі показники в основної групі зафіксовано по таким якостям особистості, як «прямолінійність» та «напруженість».

3. В основної вибірці переважна кількість опитаних має високий та достатній рівень адаптивності. Це свідчить, що ці студенти швидко адаптуються до незнайомих та стресових ситуацій, мають нервово-психічну стійкість на достатньому рівні та високу моральну нормативність. У контрольної групі трохи показники значно нижчі. Це свідчить, що студенти контрольної групи важче адаптуються до нових умов та мають особистісні особливості, які можуть спровокувати противоправні вчинки.

4. Виявлено, що представники основної групи мають набагато більш високі показники адаптації, дружелюбності та адекватні рівні домінування і стриманості у конфліктних ситуаціях. Досліджувані контрольної групи, в свою чергу, мають низьку стриманість у конфліктних ситуаціях та високий рівень схильності до вербальної та фізичної агресії. Безумовно, ці якості особистості є тригерами як агресивності, так і протиправної поведінки.

5. Аналіз стилю поведінки у конфліктних ситуаціях показав, що студентам основної групи більш притаманні таки стилі поведінки як співробітництво та компроміс. У контрольній групі це такі стилі поведінки, як конкуренція та, також, компроміс.

Таким чином, довготривалі заняття фізкультурою/спортом сприяють більшій гнучкості (керованості) агресивності, менш вираженим проявам імпульсивної, неконструктивної агресивності та легалізує іiі прояві в цілому. Пояснення цього факту вимагає подальших досліджень. Поки ж можна припустити, що наявність легалізованих, конструктивних форм агресивної поведінки як би «пом'якшують критерії запуску» мимовільних форм, які характерні для осіб, що здійснили тяжкі та особо тяжкі правопорушення.

Отримані дані дослідження фізкультурно-спортивної діяльності, як фактора легітимізації агресивності в період юності, можуть бути використані в ювенальної превенції, пенітенціарної психології, а також, вищими навчальними закладами при плануванні навчального процесу для формування фізкультурно-спортивного навантаження.

\section{ЛIТЕРАТУРА}

1. Антонян Ю.М. Психология убийства / Ю.М. Антонян. - М.: Юристь, 1997. - 304 с

2. Ашкинази А. С., Марищук В.Л. и др. Сравнительная характеристика агрессии и агрессивности у единоборцев, спортсменов других специализаций и неспортсменов // Материалы 8-го Международного конгресса «Современный олимпийский спорт и спорт для всех». Т. 1. - Алма-Аты: Мин. обр. и науки Республики Казахстан, казахская академия спорта и туризма, 2004. С. 160-162.

3. Батаршев А. В. Диагностика пограничных психических расстройств личности и поведения. - М.: Изд-во Института Психотерапии, 2004. - 320 с.

4. Березка С.В. Причина та види агресивної поведінки особистості. «Молодий вчений». - № 9 (49), 2017. c.85-89.

5. Валавко С.М., Аксенова Ю.Ю. Концепции агрессивного поведения детей дошкольного возраста: современный взгляд / Специальное образование - 2015. - № 2. С. 17-28. 4. Психология человеческой агрессивности: Хрестоматия / Сост. К.В. Сельченок. - Мн.: Харвест, 1999. - 656 с.

6. Гутман А. От ритуала к рекорду: Природа современного спорта / пер. с англ. под. ред. В. Нишукова. - М.: Изд-во Института Гайдара, 2016. - 304 с.

7. Выбойщик И.В., Шакурова З.А. Личностный многофакторный опросник Р. Кэттелла. Челябинск, Издательство ЮУрГУ, 2000. - 54 с.

8. Коваль Г.Ш. Сухарева В.А. Особливості духовної сфери засуджених за насильницькі злочини. Молодий вчений. №4 (68) квітень, 2019. С. 56-61

9. Лоренц К. Агрессия. Издательство «Римис», 2009. -352 с.

10. Методика «Личностная агрессивность и конфликтность»/ Диагностика эмоциональнонравственного развития. Ред. и сост. И.Б. Дерманова. - СПб., 2002. С. 142-146.

11. Многоуровневый личностный опросник «Адаптивность» (МЛО-АМ) А.Г. Маклакова и С.В. Чермянина // Практическая психодиагностика. Методики и тесты. / Ред. и сост. Райгородский Д.Я. Самара: Издательский Дом «БАХРАХ-М», 2006.- С. 549-672.

12. Диагностика межличностных отношений ДМО Лири / Практическая психодиагностика. Методики и тесты. Ред. и сост. Райгородский Д.Я. - Самара, 2001. С. 408-418.

13. Психологические тесты / Под ред. А.А.Карелина: В 2т. - М., 2001. - Т.2. С. 69-77

14. Шагако Д.С. Агрессия и насилие в контексте социальных взаимодействий / Д.С. Шагако // Вестник Адыгейского государственного университета. Серия 1: Регионоведение: философия, история, социология, юриспруденция, политология, культурология. - 2010. Вып. №1. 